\title{
Genetic and Pathogenic Characterization of Phacidiopycnis washingtonensis from Apple and Pacific Madrone from the Western United States
}

\author{
P. Sikdar, M. Mazzola, and C. L. Xiao ${ }^{\dagger}$
}

First author: Department of Plant Pathology, Washington State University, Pullman 99164; second author: United States Department of Agriculture-Agricultural Research Service (USDA-ARS), Tree Fruit Research Laboratory, 1104 N. Western Ave., Wenatchee, WA 98801; and third author: USDA-ARS, San Joaquin Valley Agricultural Sciences Center, 9611 S. Riverbend Ave, Parlier, CA 93648.

Accepted for publication 26 August 2018.

\begin{abstract}
Phacidiopycnis washingtonensis is the cause of speck rot of apple and leaf blight of Pacific madrone in Washington State. In total, 314 isolates were collected from apple production areas in eastern Washington and Pacific madrone in western Washington. Using eight microsatellite markers designed in this study, 58 unique multilocus haplotypes were identified. Only one of the haplotypes was shared between the apple and Pacific madrone populations. Analysis of molecular variance showed no genetic differentiation between the apple and Pacific madrone populations. Genetic variation was present within each subpopulation of apple from different geographic locations. The apple population possessed higher genotypic

diversity than the Pacific madrone population, suggesting that isolates from apple may represent an older population and could have been introduced into the native habitat of Pacific madrone. P. washingtonensis likely reproduces asexually because populations examined in this study were not in linkage equilibrium. In pathogenicity tests, representative isolates from apple and Pacific madrone all incited leaf blight on Pacific madrone and speck rot on apple fruit regardless of their host of origin. Overall, our findings indicate that the $P$. washingtonensis population in Washington State is largely asexual, with high genotypic flow and that apple, crabapple, and Pacific madrone could serve as sources of $P$. washingtonensis inoculum for these hosts.
\end{abstract}

Phacidiopycnis washingtonensis C. L. Xiao and J. D. Rogers was first described in 2005 (Xiao et al. 2005) and initially was observed to cause a postharvest fruit rot disease on apple fruit (Malus domestica Borkh.) and a twig dieback and canker disease of apple and crabapple (Malus sylvestris) trees in eastern Washington State (Kim and Xiao 2006; Xiao et al. 2009). In 2009, an unknown leaf blight disease was observed in Pacific madrone (Arbutus menziesii Pursh.) trees in the Puyallup area of western Washington, and the internal transcribed spacer sequence of the fungus isolated from diseased leaves of Pacific madrone was identical to that of $P$. washingtonensis isolated from apple (Elliott et al. 2014). This was the first report of $P$. washingtonensis occurring on a non-Rosaceous plant species. In 2010, P. washingtonensis was also reported for the first time to cause a fruit rot on persimmon (Diospyros kaki L.) in northern Italy (Garibaldi et al. 2010). In 2011, the same fungus was recovered from symptomatic apple and crabapple fruit in northern Germany and other parts of northern Europe (Weber 2011).

Because $P$. washingtonensis is a recently described pathogen in the U.S. Pacific Northwest, relationships among the populations from Pacific madrone in western Washington and from apple and crabapple in eastern Washington are not known. Understanding the genetic relationship between the two populations of $P$. washingtonensis from the apple production area in eastern Washington and Pacific madrone from western Washington State is important to understanding whether or not there is genotypic adaptation of $P$. washingtonensis based on its host of origin. In plant pathological studies, population genetic studies of a pathogen are important to understanding the evolutionary history of a pathogen

†Corresponding author: C. L. Xiao; E-mail: Chang-Lin.Xiao@ARS.USDA.GOV

*The $\boldsymbol{e}$-Xtra logo stands for "electronic extra" and indicates that one supplementary table is published online.

This article is in the public domain and not copyrightable. It may be freely reprinted with customary crediting of the source. The American Phytopathological Society, 2019. and its potential to evolve under specific environmental conditions and, thus, to the development of effective control strategies (Milgroom and Peever 2003).

Polymerase chain reaction (PCR)-based molecular markers have been commonly used in the studies of population genetics of plantpathogenic fungi. Molecular markers that have been commonly used in fungal population genetic studies include biallelic dominant markers such as random amplification of polymorphic DNA (RAPD) (Williams et al. 1990) and amplified fragment length polymorphism (Vos et al. 1995), biallelic codominant markers such as restriction fragment length polymorphisms (RFLPs) (Saiki et al. 1985), and multiallelic codominants such as microsatellites. One distinct problem with RAPDs is their low reproducibility, depending highly on PCR conditions. RFLP analysis, on the other hand, is skill intensive and time consuming. Recently, development and use of microsatellite markers has become more prominent in studies addressing the population genetics of fungal plant pathogens (Selkoe and Toonen 2006). Two main reasons have contributed to the rapid shift in methodologies utilized in the study of fungal population genetics. The first was the high number of alleles present at a single microsatellite locus, leading to high heterozygosity values and therefore enabling a dramatic reduction in the number of reference families necessary to construct the population genetic map. The second was the potential of microsatellite markers to perform genotyping by simple PCR, followed by allele sizing on polyacrylamide gels. In addition, most microsatellite regions exhibit high mutation rates that generate high levels of allele diversity necessary for genetic studies on an ecological time scale (Schlotterer 2000; Selkoe and Toonen 2006). The advantage of microsatellite markers in such genetic studies is mainly attributed to the fact that microsatellite markers are codominant and could combine multiple loci to obtain genotypes in a fast and inexpensive process and, thus, could provide a more precise and statistically powerful method to compare population diversity (Selkoe and Toonen 2006). Microsatellite-based markers have been utilized in a number of plant pathology studies, including those examining the population structure of Armillaria mellea (Baumgartner et al. 
2010), Ascochyta rabiei (Peever et al. 2004), Rhizoctonia solani AG-3PT (Ferrucho et al. 2013), Verticillium dahliae (Dung et al. 2013), and Magnaporthe oryzae (Maciel et al. 2014).

The objectives of this study were to (i) estimate the population genetic structure of $P$. washingtonensis from apple and crabapple in central Washington as well as from Pacific madrone in western Washington and (ii) determine whether isolates of $P$. washingtonensis from Pacific madrone are capable of infecting apple fruit or vice versa.

\section{MATERIALS AND METHODS}

Isolate selection and DNA extraction. In total, 318 isolates of $P$. washingtonensis were included in this study (Supplementary Table S1). These isolates were collected from three different hosts: apple fruit and crabapple (apple group) (crabapple is commonly planted as pollinizer in apple orchards, and P. washingtonensis causes a canker and dieback disease of crabapple trees) in various geographic areas in central Washington, which is the major apple production region; and Pacific madrone, in western Washington. Isolates were obtained from decayed apple fruit, infected crabapple twigs, or leaves with blight in Pacific madrone (Elliott et al. 2014; Kim and Xiao 2006; Xiao et al. 2009). All isolates were single-spore cultured and stored as mycelial plugs in $15 \%$ glycerol at $-80^{\circ} \mathrm{C}$ at the Washington State University Tree Fruit Research and Extension Center, Wenatchee, WA. The apple population was subdivided at the intrapopulation level based on the geographic areas of apple production in central Washington (i.e., Brewster, Chelan, Wenatchee, and Yakima subpopulations). The Pacific madrone population consisted of isolates obtained from blighted leaves of

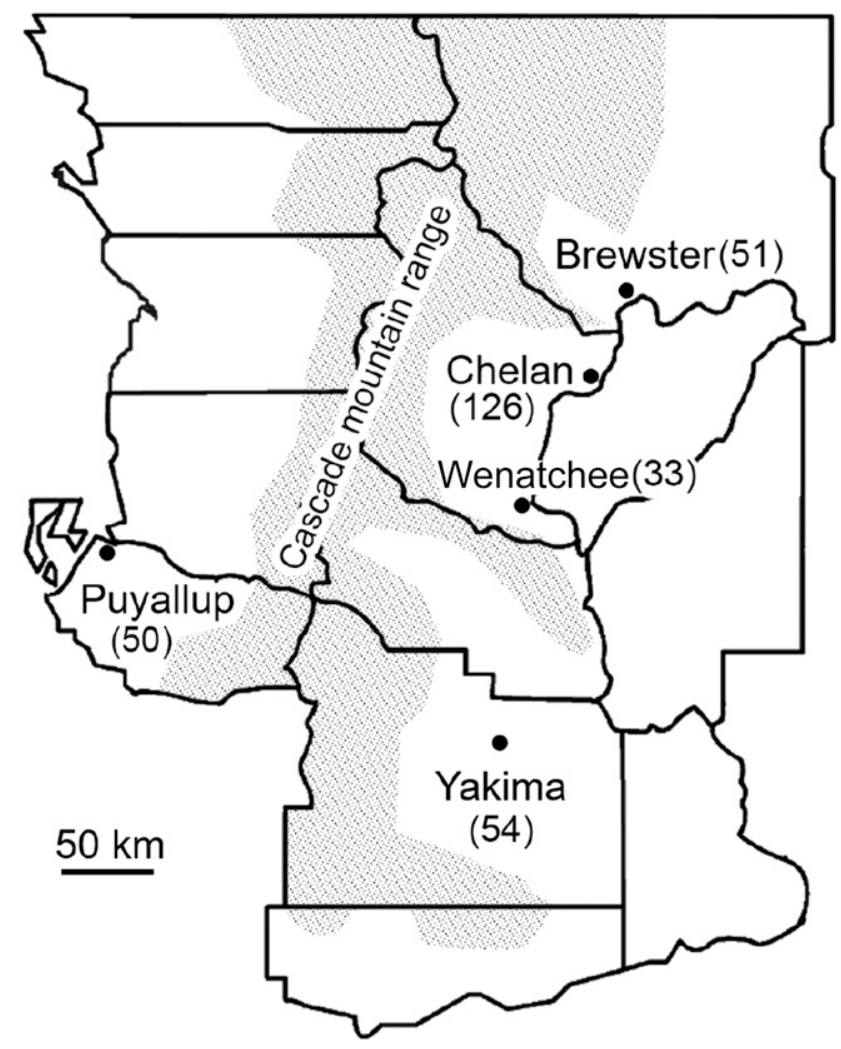

Fig. 1. Map showing geographic distribution of Phacidiopycnis washingtonensis populations from apple and Pacific madrone in Washington State. The apple population was subdivided at the intrapopulation level based on apple production districts in central Washington (i.e., Brewster, Chelan, Wenatchee, and Yakima subpopulations). The Pacific madrone population consisted of isolates obtained from blighted leaves of Pacific madrone in Puyallup, WA. Numbers in the parentheses are the numbers of isolates obtained from each location. The shaded area represents the cascade mountain range.
Pacific madrone from Puyallup, WA. The apple production in eastern Washington State is geographically separated from Pacific madrone by the Cascade mountain range (Fig. 1). There were only four isolates from persimmon from Italy.

Cultures of isolates were reactivated on potato dextrose agar (PDA) (Difco Laboratories, Detroit, MI) and incubated at $20^{\circ} \mathrm{C}$ in the dark for 5 days. The 5-day-old culture was transferred onto potato dextrose broth (PDB) (Difco Laboratories) and incubated at $20^{\circ} \mathrm{C}$ for 7 days. DNA was extracted from mycelium growing on PDB from all 318 isolates of $P$. washingtonensis using the FAST DNA kit following the manufacturer's recommendations (MP Biomedicals, Solon, $\mathrm{OH}$ ) and using the FAST Prep-24 instrument (MP Biomedicals) and stored at $-20^{\circ} \mathrm{C}$ till use.

Microsatellite enrichment. DNA isolation. For microsatellite enrichment, isolate CLX-2152, which is the living culture of the holotype of P. washingtonensis (Xiao et al. 2005), was used. In order to obtain high-quality genomic DNA, DNA was extracted using a phenol chloroform extraction method (Green and Sambrok 2012). Briefly, the lyophilized mycelium was ground in suspension with glass beads and vigorously vortexed. The ground mycelium was lysed using lysis buffer (50 mM EDTA, $100 \mathrm{mM}$ Tris $\mathrm{HCl}$ [pH 8]. and $3 \%$ sodium dodecyl sulfate [SDS]), then extracted by two organic washes followed by ethanol $(\mathrm{EtOH})$ precipitation. The resulting precipitate was resuspended in sterilized molecular-grade water and treated with RNAse. DNA was quantified spectrophotometrically using a Nanodrop 2000 (Thermo Scientific, Wilmington, DE) and by gel electrophoresis. Electrophoresis was conducted using $1 \%$ agarose gels in Tris-acetate EDTA (TAE) buffer, stained with ethidium bromide, and photographed using a UVP GelDoc-It Imaging System (Ultra Violet Products, Upland, CA).

Restriction digestion. The restriction enzymes Mbo1 and Rsa1 (New England Bioscience [NEB], Ipswich, MA) were selected for use in this study (Glenn and Schable 2005; Ozkilinc et al. 2011). Partial digestion of genomic DNA was carried out at $37^{\circ} \mathrm{C}$ for $5 \mathrm{~min}$, $10 \mathrm{~min}, 15 \mathrm{~min}, 1 \mathrm{~h}, 4 \mathrm{~h}$, and overnight.

Ligation. Two linkers were designed based on previously published data (Hamilton et al. 1999; Ozkilinc et al. 2011): SNX 24(F) (GTTTAAGGCCTAGCTAGCAGAATC) and SNX244(R) (GATTCTGCTAGCTAGGCCTTAAACAAAA), and SAULA (F) (GCGGTACCCGGGAAGCTTGG) and SAULB (R) (GATCC CAAGCTTCCCGGGTACCGC). Digested DNA was treated with $5 \mathrm{U}$ of mung bean nuclease (MBN; NEB) to remove single-stranded overhangs, incubated at $30^{\circ} \mathrm{C}$ for $30 \mathrm{~min}$, then purified using the QIAquick PCR purification kit (Qiagen, Germantown, MD). DNA was treated with $10 \mathrm{U}$ of calf intestinal phosphatase (NEB), incubated at $37^{\circ} \mathrm{C}$ for $3 \mathrm{~h}$, then purified using the QIAquick PCR purification kit (Qiagen). The digested, MBN-treated, dephosphorylated, or processed DNA was then ligated to the doublestranded linkers listed above. Prior to ligation, double-stranded linkers were prepared by adding equimolar amounts of each linker with $100 \mathrm{mM} \mathrm{NaCl}$, denatured at $95^{\circ} \mathrm{C}$ for $5 \mathrm{~min}$, then incubated at room temperature for $2 \mathrm{~h}$. Ligations were conducted in a 30- $\mu \mathrm{l}$ reaction mixture containing $1 \times$ NEB buffer 4 (NEB), $0.2 \mathrm{mM}$ dNTP (Promega Corp., Madison, WI), $5 \mu \mathrm{M}$ each processed forward and reverse linker primers; $10 \times$ bovine serum albumen (NEB); $1 \mathrm{U}$ of $\mathrm{Xmn} 1(\mathrm{NEB}) ; 1,000 \mathrm{U}$ of ligase (NEB), and10 $\mu \mathrm{l}$ of the processed DNA. The reaction was conducted in a My-Cycler thermocycler (Bio-Rad, Hercules, CA) for cycles of $16^{\circ} \mathrm{C}$ for $30 \mathrm{~min}$ and $37^{\circ} \mathrm{C}$ for 10 min overnight.

Efficacy of ligation was examined by PCR which was conducted using $2 \mu$ l of ligated DNA, $1 \times$ PCR buffer (Promega Corp.), $2.5 \mathrm{mM}$ $\mathrm{MgCl}_{2}$ (Promega Corp.), $0.2 \mathrm{mM} \mathrm{dNTP}$ (Promega Corp.), $1 \mu \mathrm{M}$ only forward primers of linkers (as listed above), and 1.25 $\mathrm{U}$ of Taq polymerase (Promega Corp.). The reaction was carried out in a My-Cycler thermocycler (Bio-Rad) using the following conditions: initial denaturing at $95^{\circ} \mathrm{C}$ for $5 \mathrm{~min} ; 30$ cycles of denaturing at $95^{\circ} \mathrm{C}$ for $45 \mathrm{~s}$, annealing at $58^{\circ} \mathrm{C}$ for $45 \mathrm{~s}$, and extension at $72^{\circ} \mathrm{C}$ for $1.5 \mathrm{~min}$; and final extension at $72^{\circ} \mathrm{C}$ for $10 \mathrm{~min}$ followed by a 
final hold at $4{ }^{\circ} \mathrm{C}$. Resulting products were viewed by electrophoresis in $2 \%$ agarose gels in TAE buffer, and photographed using a UVP GelDoc-It Imaging System (Ultra Violet Products).

Hybridization of biotinylated oligonucleotide repeat motifs with linker ligated DNA. The 3' end biotin-tagged microsatellite repeat motif containing oligonucleotides of 24 to 30 bases in length were designed using Operon online primer design. Three repeat motifs$(\mathrm{CA})_{10},(\mathrm{CAA})_{8}$, and $(\mathrm{CT})_{10}$-were used in hybridization reactions. The reaction was carried out in a $50-\mu l$ total volume with $25 \mu \mathrm{l}$ of $2 \times$ hybridization solution ( $12 \times$ saline sodium citrate and $0.2 \%$ SDS), $10 \mu \mathrm{l}$ of biotinylated microsatellite probe (Operon), $10 \mu \mathrm{l}$ of linker ligated DNA (from the previous step), and $5.0 \mu \mathrm{l}$ of sterilized deionized water. The samples were incubated in a My-Cycler thermocycler (Bio-Rad) at $95^{\circ} \mathrm{C}$ for $15 \mathrm{~min}$, ramped down to $70^{\circ} \mathrm{C}$ for $4 \mathrm{~h}$, then slowly ramped down to $50^{\circ} \mathrm{C}$ by decreasing temperature by $0.2^{\circ} \mathrm{C}$ every $5 \mathrm{~s}$ for 99 cycles, kept at $50^{\circ} \mathrm{C}$ for $10 \mathrm{~min}$, and again ramped down to $40^{\circ} \mathrm{C}$ by decreasing $0.2^{\circ} \mathrm{C}$ every $5 \mathrm{~s}$ for 25 cycles, with a final hold at $15^{\circ} \mathrm{C}$ overnight.

Dynabead enrichment of microsatellite containing DNA fragments. Dynabead Streptavidin Coated M280 (Invitrogen, Grand Island, NY) was used to capture the biotin-tagged microsatellite hybridized DNA in a magnetic field. Streptavidin-coated magnetic beads ( $50 \mu \mathrm{l}$; Invitrogen) were placed in $1.5-\mathrm{ml}$ microcentrifuge tubes and beads were bound to the biotin-tagged microsatellite hybridized DNA target in a magnetic particle concentrator (MPC; Invitrogen) for $5 \mathrm{~min}$. The beads were then washed four times in $200 \mu \mathrm{l}$ of $1 \times$ washing buffer (with $10 \mathrm{mM}$ Tris $\mathrm{HCl}$ [pH7.5], $1 \mathrm{mM}$ EDTA, and $2 \mathrm{M} \mathrm{NaCl}$ ), then washed twice in $1 \times$ hybridization solution, with a final suspension of beads in $150 \mu \mathrm{l}$ of hybridization solution. Subsequently, the DNA coated magnetic bead sample suspended in hybridization solution was incubated at $37^{\circ} \mathrm{C}$ on a shaker for $2 \mathrm{~h}$. The hybridized solution was placed in the MPC and the supernatant was removed. The beads were washed twice in $200 \mu \mathrm{l}$ of $2 \times$ buffer and then twice in $1 \times$ buffer followed by a final two washes with $200 \mu \mathrm{l}$ of $1 \times$ buffer, with a10-min incubation at $50^{\circ} \mathrm{C}$ between these two washes. Beads were suspended in $200 \mu \mathrm{l}$ of $0.1 \mathrm{mM}$ Tris low-EDTA (TLE) buffer and incubated for $5 \mathrm{~min}$ at $95^{\circ} \mathrm{C}$; then, quickly, the supernatant was separated using the MPC and collected in a new tube. To these tubes, $22 \mu \mathrm{l}$ of NaOAc/EDTA buffer and $444 \mu \mathrm{l}$ of $95 \% \mathrm{EtOH}$ were added and DNA was precipitated by centrifugation at 13,500 rpm for $10 \mathrm{~min}$ (Eppendorf Centrifuge 5417c; Eppendorf, Hauppauge, NY). The pellet was washed twice with $0.5 \mathrm{ml}$ of $70 \%$ ice-cold EtOH and centrifuged at $13,500 \mathrm{rpm}$ for $1 \mathrm{~min}$. Finally, the pellet was air dried and then resuspended in $25 \mu \mathrm{l}$ of TLE prior to incubation overnight at $-20^{\circ} \mathrm{C}$.

$P C R$ to validate hybridization. In a reaction volume of $25 \mu \mathrm{l}, 2 \mu \mathrm{l}$ of microsatellite repeat motif enriched DNA (Glenn and Schable 2005) was added with $1 \times$ PCR buffer (Promega Corp.), $2.5 \mathrm{mM}$ $\mathrm{MgCl}_{2}$ (Promega Corp.), $0.2 \mathrm{mM}$ dNTP (Promega Corp.), $1 \mu \mathrm{M}$ forward linker primers, and $1.25 \mathrm{U}$ of Taq polymerase (Promega
Corp.). The reaction was carried out with the same thermocycling condition used for testing the ligation reaction and visualized in $2 \%$ agarose gels using a UVP GelDoc-It Imaging System (Ultra Violet Products)

Ligation of hybridized microsatellite repeat motif-enriched DNA into plasmid. The PCR product of microsatellite repeat motifenriched DNA from the prior step (Glenn and Schable 2005) was then ligated to TA-TOPO plasmid (Invitrogen) using the manufacturer's protocol. Positive clone colonies were then selected, plasmid DNA was extracted, and inserts were sequenced using a sequencing reaction total volume of $10 \mu$ l containing 0.5 to $1 \mu \mathrm{g}$ of DNA, $3.2 \mathrm{pmol}$ of primer, $4 \mu \mathrm{l}$ of Big Dye Terminator Cycle Sequencing Ready Reaction Mix (Applied Biosystem, Foster City, CA), and sterile distilled water. The thermocycling conditions for cycle sequencing reaction consisted of 25 cycles $95^{\circ} \mathrm{C}$ for $15 \mathrm{~s}, 50^{\circ} \mathrm{C}$ for $15 \mathrm{~s}$, and then $60^{\circ} \mathrm{C}$ for $4 \mathrm{~min}$. Products from the sequencing reaction were purified using a Centriflex Gel Filtration Cartridge (Edge Biosystem, Gaithersburg, MD) and dried in a rotatory evaporator (Vacufuge Plus; Eppendorf). Sequences of the dried samples were read in ABI PRISM377 (Applied Biosystem, Grand Island, NY) at Washington State University Molecular Core facilities in Pullman.

Marker design. All resulting DNA sequences were screened using an online microsatellite repeat-motif-finding program (microsatellite repeats finder [http://insilico.ehu.es/mini_tools/ microsatellites]) and primers were designed using the online primer-designing program Primer 3 (Koressaar and Remm 2007). Primers were designed using the 100-bp region upstream and downstream from the repeat motifs (Table 1), then screened against 20 representative isolates of $P$. washingtonensis. PCRs were conducted in a total volume of $25 \mu \mathrm{l}$ using the following components: $10 \mathrm{ng}$ of fungal genomic DNA, $0.5 \mu \mathrm{M}$ each forward and reverse primer, $0.2 \mathrm{mM}$ dNTP (Promega Corp.), $1 \times$ Go Taq Buffer (Promega Corp.), $2.5 \mathrm{mM} \mathrm{MgCl}_{2}$ (Promega Corp.), and $2 \mathrm{U}$ of GoTaq DNA Polymerase (Promega Corp.). PCR was conducted using the following thermocycling conditions: an initial denaturing step at $95^{\circ} \mathrm{C}$ for $5 \mathrm{~min}$; followed by 44 cycles of denaturation at $94^{\circ} \mathrm{C}$ for $90 \mathrm{~s}$, annealing at temperature gradient of 55 to $65^{\circ} \mathrm{C}$ for $90 \mathrm{~s}$, and extension at $72^{\circ} \mathrm{C}$ for $90 \mathrm{~s}$; and final extension at $72^{\circ} \mathrm{C}$ for $10 \mathrm{~min}$. Optimal annealing temperatures are given in Table 1 . The PCR products were separated on 3\% high-resolution agarose gels and fragments were visualized as described above in the microsatellite enrichment section.

Microsatellite PCR. Twenty primer pairs were selected initially (data not shown) and eight (Table 1) were used for the subsequent analysis of $P$. washingtonensis population genetic structure. These eight markers were selected based on higher number of alleles per marker and higher polymorphism when screened with 20 representative isolates of $P$. washingtonensis (data not shown). The forward primer of each primer pair was tagged with M13 (CACGACGTTGTAAAACGAC) at the 5' end. An initial PCR was conducted using the same reaction conditions described

TABLE 1. Microsatellite markers, including the repeat sequence and annealing temperature, used in this study

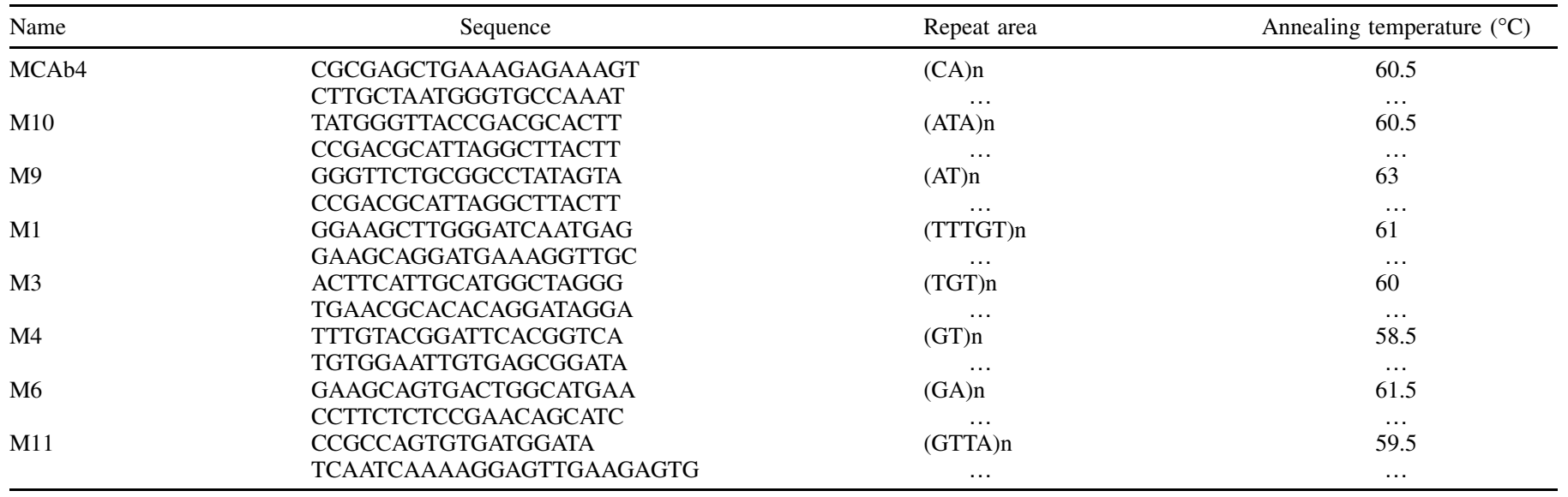


above, except for the inclusion of $0.6 \mu \mathrm{m}$ M13-tailed forward primer. Verification and visualization of the resulting PCR product was conducted as above. The PCR product was purified using the QIA quick PCR purification Kit (Qiagen) and a second PCR was conducted using $20 \mathrm{ng}$ of PCR-purified DNA as template. DNA was amplified using $0.3 \mu \mathrm{m}$ D4-labeled (Sigma-Aldrich, St. Louis) forward primer and $0.3 \mu \mathrm{m}$ the same reverse primer as noted above. The products were again verified by gel electrophoresis, and $10 \mu \mathrm{l}$ of the resulting PCR product was then precipitated with $2 \mu$ of $3 \mathrm{M}$ sodium acetate (pH 5.2), $2 \mu \mathrm{l}$ of 100 mM EDTA ( $\mathrm{pH} 8), 1 \mu \mathrm{l}$ of glycogen at $20 \mathrm{mg} / \mathrm{ml}$, and $60 \mu \mathrm{l}$ of $95 \%$ ice-cold EtOH and pelleted by centrifuged at $4,300 \mathrm{rpm}$ for $20 \mathrm{~min}$ at $4^{\circ} \mathrm{C}$. The pellet was washed twice in $200 \mu \mathrm{l}$ of $75 \%$ ice-cold EtOH for 5 min each time at $4,300 \mathrm{rpm}$ and $4^{\circ} \mathrm{C}$. The washed pellet was dried in a thermocycler for $10 \mathrm{~min}$ at $60^{\circ} \mathrm{C}$. The pellets were suspended in sample loading solution buffer (Beckman Coulter, Brea, CA) along with a D1labeled 600-bp marker (Beckman Coulter) and fragments were analyzed using a Beckman Coulter CEQ 8000 fragment analyzer.

Pathogenicity tests. Ten isolates of $P$. washingtonensis were selected based on the haplotypes $(\mathrm{H})$ obtained after initial population structure analysis. H31 was a major haplotype from apple and H45 was found to be shared between isolates from Pacific madrone and apple. Thus, isolates belonging to haplotypes $\mathrm{H} 31$ and H45 were used in the pathogenicity tests. Isolates 2706 (H31), 3101 (H31), 3045(H31), 4185(H31), and 4183 (H45) from apple and 8307(H42), 8308(H47), 8309(H47), 8345(H45), and 8347(H45) from Pacific madrone were used for pathogenicity tests. All isolates were initially stored in $-80^{\circ} \mathrm{C}$ glycerol and were revived on PDA for inoculum preparation.

Potted Pacific madrone trees were used to conduct pathogenicity tests in the greenhouse. All potted trees used for this experiment were 3 years old, with no visible signs of diseases, and were originally obtained from the Washington State University Puyallup Research and Extension Center, Puyallup. For each isolate of $P$. washingtonensis and inoculation method used in pathogenicity assays, three representative Pacific madrone trees were selected, five leaves per replicate tree per treatment were used to conduct the inoculation, and the experiment was conducted twice. Prior to inoculation, leaves were surface sterilized by spraying with $70 \%$ $\mathrm{EtOH}$, then air dried. Inoculum consisted of a mycelial plug $(5 \mathrm{~mm}$ in diameter) excised from the margin of a 6-day-old culture of $P$. washingtonensis on PDA. Three inoculation treatments were used: (i) cold treatment of a 5-by-5- $\mathrm{mm}^{2}$ leaf area using Freze-it aerosol (Intercon Chemical, St. Louis) for $5 \mathrm{~s}$, which predisposed the sprayed area to $-50^{\circ} \mathrm{C}$, followed by inoculation with fungal mycelial plug (cold treated/inoculated); (ii) a fungal mycelial plug used to inoculate the $5-$ by $-5-\mathrm{mm}^{2}$ area on the leaf without cold predisposition (noncold treated/inoculated); and (iii) a noninoculated control. Inoculated areas of leaves were wrapped in moist cheesecloth for 15 days and leaves were enclosed in moist plastic bags at $100 \%$ relative humidity (recorded by data logger) (Watchdog450; Spectrum Technologies, Inc., Plainfield, IL) for $15 \mathrm{~h}$. During the entire experiment in the greenhouse, temperature was maintained between 20 and $25^{\circ} \mathrm{C}$. Disease symptoms were recorded from 15 days postinoculation (dpi). Disease incidence was recorded as percentage of leaves with blight symptoms in the total leaves in each treatment. Disease severity was calculated because there were visual differences (among the isolates used for inoculation) in disease severity over time. Percent leaf surface exhibiting blight symptoms was recorded at $15,20,25,30$, and 35 dpi. Disease severity was defined using the area under the disease progress curve (AUDPC) formula $\sum i_{n-1}\left[\left(Y_{i}+Y_{i+1}\right) / 2\right]\left(t_{i+1}-t_{i}\right)$, where $Y_{i}=$ disease rating in terms of area of leaf with blight (in square millimeters) at the $i$ th observation, $t_{i}=$ time (days postinoculation) at the $i$ th observation, and $n=$ number of observations (Dung et al. 2013). After $35 \mathrm{dpi}$, inoculated leaves were brought back to the laboratory and surface sterilized with $70 \% \mathrm{EtOH}$, and reisolations of $P$. washingtonensis were attempted on PDA both from the margin of healthy and diseased leaves as well as from the center of tissue exhibiting blight symptoms.

Pathogenicity tests also were conducted in the laboratory using organic Red Delicious fruit obtained from a local fruit packinghouse. The fruit were surface disinfected by washing them in $0.5 \%$ $\mathrm{NaOCl}$ for $5 \mathrm{~min}$ followed by washing three times in sterile water at 5-min intervals. The experiment included three replicates, each with 10 fruit for each isolate of $P$. washingtonensis, and the experiment was conducted twice. Inoculum was prepared by growing P. washingtonensis isolates on PDA for 4 to 5 days at $20^{\circ} \mathrm{C}$ prior to transferring to oatmeal agar (OMA) (60 $\mathrm{g}$ of finely ground iron- and zinc-fortified oatmeal [Gerber, Fremont, $\mathrm{MI}$ ] and $15 \mathrm{~g}$ of agar in 1 liter of deionized water autoclaved at $121^{\circ} \mathrm{C}$ for $90 \mathrm{~min}$ ). OMA cultures were incubated for 10 to 14 days in alternating 12 -h light and dark periods at $20^{\circ} \mathrm{C}$. The oozing pycnidia from this culture were used to prepare spore suspensions of $5 \times 10^{5}$ conidia $/ \mathrm{ml}$. For inoculations, a 2-mm-diameter wound was created on the fruit skin using a sterilized finished nail head and $10 \mu \mathrm{l}$ of the spore suspension was pipetted into the wound site. Inoculated apple fruit were incubated on sterilized muffin trays inside plastic crispers, lined with moist paper towels in dark at room temperature for 10 days. Control treatments consisted of mock inoculations with sterilized deionized water. Disease symptoms were noted $10 \mathrm{dpi}$ and incidence of disease was calculated as the percentage of apple showing symptoms. Disease symptoms appeared at different days postinoculation; thus, lesion development and diameter was monitored and disease severity index was determined based on lesion diameter. Lesion diameter was recorded at 10,13,16, 19, and 22 dpi. Disease severity was defined using the AUDPC formula $\Sigma_{i n-1}\left[\left(Y_{i}+Y_{i+1}\right) / 2\right]\left(t_{i+1}-t_{i}\right)$ (Dung et al. 2013), where $Y_{i}=$ disease rating in terms of lesion diameter $(\mathrm{mm})$ at the $i$ th observation, $t_{i}=$ time (days postinoculation) at the $i$ th observation, and $n=$ number of observations. After $22 \mathrm{dpi}$, fruit were surface sterilized with $70 \%$ $\mathrm{EtOH}$ and reisolation of $P$. washingtonensis was attempted from inoculated fruit by plating diseased tissue onto PDA.

Data analysis. Estimates of genetic diversity and genotypic richness, evenness, and diversity. Nei's expected heterozygosity $\left(\mathrm{H}_{\mathrm{exp}}\right)$, which is equivalent to genetic diversity in haploid organisms and defined as the probability that two randomly selected haplotypes are different (Nei 1973), was calculated using the software Arlequin, ver.3.5 (Excoffier et al. 2005). Expected heterozygosity was also calculated for each locus in Arlequin using both nonclonecorrected and clone-corrected data sets. Heterozygosity values from apple and Pacific madrone groups were compared using the MannWhitney $U$ test (Mann and Whitney 1947). Multilocus microsatellite genotypes or haplotypes were determined using Arlequin, ver. 3.5. To determine the proportion of isolates in the sample due to asexual reproduction, clonal fraction $(\mathrm{CF})[1-\{$ (observed number of genotype)/(total number of isolates) $\}$ ] (Ferrucho et al. 2013; Zhan et al. 2003) was calculated. CF values close to 1 imply that the sample monitored is largely asexual in its mode of reproduction. The observed number of genotypes $\left(g_{\text {obs }}\right)$ was obtained based on the total number of unique multilocus haplotypes observed in each sample group in the poppr package of $\mathrm{R}$ studio, version 3.01 (Grünwald et al. 2003; Kamvar et al. 2013). The number of haplotypes expected in each sample group after correcting for the smallest sample size $\left(g_{\text {exp }}\right)$ from clone-corrected data $(n=5$; representing the smallest sample size in clone-corrected data from Puyallup population) was calculated using 10,000 jackknife replicates in GenoDive, ver.1.1 (Meirmans and Van Tienderen 2004). Multilocus genotypic diversity was estimated using Shannon-Wieners $\mathrm{H}^{\prime}$ and Stoddart and Taylor's G (Grünwald et al. 2003; Stoddart and Taylor 1988), while multilocus genotypic evenness was estimated using the index E5 (Grünwald et al. 2003). Indices of multilocus genotypic diversity, evenness, and $95 \%$ confidence intervals were calculated using 10,000 bootstrap replicates in the poppr package under $\mathrm{R}$ Studio, version 3.0 (Grünwald et al. 2003; Kamvar et al. 2013). Genotypic indices were 
considered significantly different if there was no overlap of $95 \%$ confidence intervals. Subsequent analyses were conducted using clone-corrected data and default software parameters under the stepwise mutation model, unless otherwise noted (Ohta and Kimura 1973), in GenoDive, ver.1.1 (Meirmans and Van Tienderen 2004). Index of association $\left(\mathrm{I}_{\mathrm{A}}\right)$ and standardized index of association (rBarD) (Agapow and Burt 2001) were estimated for both the nonclone-corrected full sample data set and clone-corrected data set using the poppr package in R Studio (Kamvar et al. 2013) to test the null hypothesis of random association of loci due to mating.

Genetic differentiation between populations. Slatkin's Rst was estimated (Slatkin 1995) and pairwise comparisons of isolates collected in different geographic areas from infected apple fruit and twigs and Pacific madrone leaves were performed to determine whether populations differed genetically due to adaptation on a particular host or adaptation within a geographic location. Pairwise comparisons of populations from apple and crabapple, Pacific madrone, and persimmon were also conducted. Pairwise comparisons between populations from the apple group and Pacific madrone were also conducted. All pairwise comparisons were performed using the sequential Bonferroni method (Rice 1989) and 16,000 permutations in Arlequin 3.5 (Excoffier et al. 2005).

Analysis of molecular variance (AMOVA) was performed using Arlequin 3.5 to test the null hypothesis that $P$. washingtonensis populations associated with apple, crabapple, and Pacific madrone are not genetically differentiated. AMOVA was also conducted to test the null hypothesis that populations of $P$. washingtonensis from different geographical locations from apple and Pacific madrone are not significantly differentiated. AMOVA was performed using both nonclone-corrected and clone-corrected data sets with 16,000 permutations. To understand the association of different subpopulations from different geographic locations, principle coordinate analysis (PCoA) using Nei's unbiased expected heterozygosity indices was plotted using Genalex 6.1 (Baumgartner et al. 2010; Dung et al. 2013; Ozkilinc et al. 2010; Peakall and Smouse 2006). To understand the origin of different pathogen populations, the minimum spanning network for populations of $P$. washingtonensis was estimated using Bruvo's genetic distance (Bruvo et al. 2004) calculated in the poppr package of R Studio (Grünwald et al. 2003, Kamvar at al. 2013) and plotted and visualized in the poppr package of R Studio (Kamvar et al. 2013).

Pathogenicity test. For both pathogenicity tests conducted on apple and Pacific madrone, AUDPC for each isolate from different haplotypes was subjected to analysis of variance (ANOVA) and means separation was conducted using Tukey's test in SAS (version 9.3; SAS Institute, Cary, NC). For isolates belonging to the same genotype but different geographic location, a separate ANOVA was conducted to test whether there are significant differences in aggressiveness of pathogens based on their geographic location using Proc ANOVA in SAS.

\section{RESULTS}

Marker development. In all, 90 positive clones with inserts were selected for sequencing, of which only 20 had inserts with microsatellite repeat regions. These 20 sequences were then used to develop 20 potential markers which were screened against an initial 20 isolates of $P$. washingtonensis, and all markers showed polymorphism at the respective locus (data not shown). Based on sequence analysis, the presence of the desired repeat sequence was confirmed. Of the 20 markers, 8 were selected for further analysis (Table 1) based upon the length of the microsatellite repeat region and observed polymorphic alleles per locus (data not shown).

Genetic differentiation among and within populations from apple, crabapple, and Pacific madrone. In total, 58 haplotype groups were identified among the 318 isolates analyzed from the different hosts and geographic regions (Table 2). Within the apple group population, 52 multilocus haplotypes were identified, and all of these haplotypes were present among the 226 isolates from apple, with a $\mathrm{CF}$ of 0.78 . Of the 52 haplotypes, 5 haplotypes $(\mathrm{H} 2, \mathrm{H} 6, \mathrm{H} 7, \mathrm{H} 31$, and $\mathrm{H} 36)$ were present among the 38 isolates from crabapple $(\mathrm{CF}=0.87)$. In the Pacific madrone population consisting of 50 isolates, five haplotypes were identified $(\mathrm{CF}=0.89)$. One unique multilocus haplotype was identified in the four isolates from persimmons $(\mathrm{CF}=0.75)$. Nei's heterozygosity

TABLE 2. Multilocus haplotypes of Phacidiopycnis washingtonensis identified in this study and their corresponding multilocus microsatellite genotypes or haplotypes expressed in terms of size of alleles (in base pairs) at eight locia

\begin{tabular}{|c|c|c|c|c|c|c|c|c|}
\hline \multirow[b]{2}{*}{ Haplotype } & \multicolumn{8}{|c|}{ Loci } \\
\hline & 1 & 2 & 3 & 4 & 5 & 6 & 7 & 8 \\
\hline H1 & 73 & 212 & 217 & 77 & 77 & 88 & 66 & 234 \\
\hline $\mathrm{H} 2$ & 73 & 212 & 217 & 77 & 101 & 208 & 66 & 234 \\
\hline H3 & 73 & 212 & 217 & 89 & 101 & 84 & 72 & 268 \\
\hline H4 & 73 & 212 & 217 & 97 & 79 & 170 & 72 & 268 \\
\hline H5 & 73 & 212 & 221 & 77 & 221 & 122 & 66 & 268 \\
\hline H6 & 83 & 101 & 217 & 77 & 101 & 74 & 120 & 78 \\
\hline $\mathrm{H} 7$ & 83 & 101 & 221 & 81 & 89 & 122 & 66 & 84 \\
\hline H8 & 83 & 101 & 221 & 89 & 79 & 170 & 84 & 78 \\
\hline H9 & 83 & 212 & 217 & 77 & 73 & 122 & 72 & 268 \\
\hline $\mathrm{H} 10$ & 83 & 212 & 221 & 89 & 101 & 78 & 72 & 268 \\
\hline H11 & 83 & 221 & 187 & 89 & 101 & 84 & 108 & 234 \\
\hline H12 & 195 & 101 & 217 & 73 & 74 & 78 & 84 & 112 \\
\hline H13 & 195 & 101 & 217 & 77 & 123 & 122 & 90 & 234 \\
\hline H14 & 195 & 101 & 217 & 89 & 73 & 170 & 84 & 112 \\
\hline H15 & 195 & 101 & 217 & 97 & 79 & 122 & 66 & 268 \\
\hline H16 & 195 & 101 & 217 & 97 & 159 & 122 & 84 & 72 \\
\hline H17 & 195 & 101 & 217 & 101 & 82 & 169 & 84 & 72 \\
\hline H18 & 195 & 101 & 217 & 101 & 84 & 122 & 84 & 72 \\
\hline H19 & 195 & 101 & 217 & 101 & 101 & 122 & 84 & 72 \\
\hline $\mathrm{H} 20$ & 195 & 101 & 221 & 81 & 74 & 78 & 66 & 78 \\
\hline $\mathrm{H} 21$ & 195 & 212 & 187 & 77 & 101 & 78 & 66 & 78 \\
\hline $\mathrm{H} 22$ & 195 & 212 & 187 & 101 & 77 & 121 & 66 & 234 \\
\hline $\mathrm{H} 23$ & 195 & 212 & 217 & 69 & 73 & 74 & 66 & 78 \\
\hline $\mathrm{H} 24$ & 195 & 212 & 217 & 69 & 74 & 70 & 66 & 268 \\
\hline $\mathrm{H} 25$ & 195 & 212 & 217 & 69 & 79 & 84 & 66 & 84 \\
\hline $\mathrm{H} 26$ & 195 & 212 & 217 & 73 & 79 & 120 & 84 & 114 \\
\hline $\mathrm{H} 27$ & 195 & 212 & 217 & 77 & 74 & 76 & 90 & 114 \\
\hline $\mathrm{H} 28$ & 195 & 212 & 217 & 77 & 77 & 74 & 120 & 234 \\
\hline $\mathrm{H} 29$ & 195 & 212 & 217 & 77 & 77 & 78 & 78 & 112 \\
\hline H30 & 195 & 212 & 217 & 77 & 77 & 78 & 84 & 234 \\
\hline H31 & 195 & 212 & 217 & 77 & 77 & 122 & 72 & 234 \\
\hline H32 & 195 & 212 & 217 & 77 & 79 & 84 & 90 & 112 \\
\hline H33 & 195 & 212 & 217 & 77 & 81 & 78 & 66 & 268 \\
\hline H34 & 195 & 212 & 217 & 77 & 81 & 80 & 108 & 234 \\
\hline H35 & 195 & 212 & 217 & 77 & 81 & 84 & 72 & 122 \\
\hline H36 & 195 & 212 & 217 & 77 & 152 & 122 & 78 & 234 \\
\hline H37 & 195 & 212 & 217 & 77 & 159 & 88 & 72 & 234 \\
\hline H38 & 195 & 212 & 217 & 77 & 221 & 78 & 66 & 234 \\
\hline H39 & 195 & 212 & 217 & 89 & 77 & 170 & 84 & 234 \\
\hline $\mathrm{H} 40$ & 195 & 212 & 217 & 89 & 99 & 278 & 66 & 234 \\
\hline H41 & 195 & 212 & 217 & 89 & 101 & 84 & 66 & 112 \\
\hline $\mathrm{H} 42$ & 195 & 212 & 217 & 89 & 286 & 84 & 78 & 234 \\
\hline $\mathrm{H} 43$ & 195 & 212 & 217 & 97 & 75 & 84 & 72 & 234 \\
\hline $\mathrm{H} 44$ & 195 & 212 & 217 & 97 & 77 & 78 & 78 & 234 \\
\hline $\mathrm{H} 45$ & 195 & 212 & 217 & 97 & 79 & 122 & 78 & 268 \\
\hline H46 & 195 & 212 & 217 & 97 & 81 & 170 & 66 & 234 \\
\hline $\mathrm{H} 47$ & 195 & 212 & 217 & 97 & 173 & 122 & 78 & 234 \\
\hline $\mathrm{H} 48$ & 195 & 212 & 217 & 101 & 75 & 78 & 78 & 234 \\
\hline H49 & 195 & 221 & 217 & 77 & 73 & 84 & 72 & 234 \\
\hline H50 & 195 & 248 & 217 & 77 & 77 & 76 & 84 & 112 \\
\hline H51 & 195 & 248 & 217 & 77 & 101 & 84 & 66 & 112 \\
\hline H52 & 199 & 212 & 217 & 77 & 82 & 84 & 72 & 112 \\
\hline H53 & 199 & 212 & 217 & 77 & 221 & 78 & 66 & 112 \\
\hline H54 & 597 & 212 & 217 & 77 & 77 & 74 & 66 & 112 \\
\hline H55 & 597 & 212 & 217 & 77 & 82 & 84 & 66 & 112 \\
\hline H56 & 597 & 272 & 217 & 125 & 73 & 88 & 72 & 234 \\
\hline H57 & 195 & 101 & 217 & 101 & 101 & 122 & 101 & 72 \\
\hline H58 & 73 & 101 & 221 & 89 & 77 & 84 & 72 & 112 \\
\hline
\end{tabular}

a Haplotype is defined by the size of allele expressed in terms of base pair size of nucleotides (bp) at each locus (generated in Arlequin 3.5) (Excoffier et al. 2005). Here, eight loci were examined across the population and there was no missing value for any locus examined. 
$\left(\mathrm{H}_{\mathrm{exp}}\right)($ Nei 1973) from the total nonclone-corrected data set was 0.65 (Table 3$)\left(\mathrm{H}_{\exp }\right.$ ranges from 0 to 1 , where 0 implies no genetic diversity and 1 absolute genetic identity). $\mathrm{H}_{\exp }$ was 0.648 from the apple group population and 0.3168 from Pacific madrone. The differences in $\mathrm{H}_{\text {exp }}$ values between the populations from different hosts were statistically significant $(P=0.04)$. Genotypic diversity (Shannon-Wiener genotypic diversity index and Stoddard-Taylor genotypic diversity index) indices were higher in subpopulations from apple and crabapple at various geographic locations versus the population from Pacific madrone from the Puyallup area (Table 3 ). Overall, observed multilocus-genotype or genotypic richness $\left(g_{\text {obs }}\right)$ was higher in the subpopulation from apple (highest $g_{\text {obs }}=38$ in apple population from Chelan area) compared with that from Pacific madrone $\left(g_{\text {obs }}=5\right)$ (Table 3$)$. Estimated genotypic richness when corrected for smallest sample size in clone-corrected data $(n=$ 5) was also greatest in apple $\left(g_{\exp }=10\right)$ compared with Pacific madrone $\left(g_{\text {exp }}=5\right)$ (Table 3$)$.

When pairwise comparison of the $P$. washingtonensis population from apple was done with the crabapple population, the $R$ st value was 0.216 , indicating a low difference between these two groups (Table 4). The pairwise $R$ st value between the apple group population (subpopulations from apple and crabapple together) and the Pacific madrone population was 0.180 , indicating a low genetic difference between the two populations. AMOVA of the nonclone-corrected data showed that there was $-8.00 \%$ genetic variation among the isolates from three different hosts (apple, $\mathrm{Pa}-$ cific madrone, and persimmon), and the negative percent variation value was not statistically significant $(P=0.60)$. AMOVA for clonecorrected data also showed that the genetic variation between the apple group population and Pacific madrone population was not statistically significant $(P=0.57)$ (Table 5).

Genetic differentiation of populations from different geographic locations. In total, 12 of the 58 haplotypes were distributed among the subpopulations from different geographic locations. Seven haplotypes occurred in the Brewster subpopulation and haplotype H11 constituted $49.2 \%$ of the total sample size. Among haplotypes represented in the Brewster subpopulations, haplotypes $\mathrm{H} 2$ and $\mathrm{H} 3$ also occurred in the Chelan subpopulation; $\mathrm{H} 2, \mathrm{H} 3$, and $\mathrm{H} 41$ also occurred in the Wenatchee subpopulation; and H41 was found in the Yakima subpopulation. Thirty haplotypes were present in the Chelan subpopulation and haplotype H31 was the most prominent, representing $15.5 \%$ of the isolates. Of 30 haplotypes in the Chelan subpopulation, 8 were shared with subpopulations from Brewster $(\mathrm{H} 2$ and $\mathrm{H} 3)$, Wenatchee $(\mathrm{H} 2, \mathrm{H} 3$, $\mathrm{H} 10, \mathrm{H} 31, \mathrm{H} 35$, and H49), and Yakima (H31, H33, H36, and H56). The Wenatchee subpopulation had 15 haplotypes and haplotype H45 constituted the maximum portion (25\%) of the total population size. Three haplotypes were shared with the Brewster subpopulation $(\mathrm{H} 2, \mathrm{H} 3$, and H41), six with Chelan $(\mathrm{H} 2, \mathrm{H} 3, \mathrm{H} 10, \mathrm{H} 31, \mathrm{H} 35$, and H49), three with Yakima (H31, H34, and H41) and one with Puyallup (H45). The Yakima subpopulation had 15 haplotypes and haplotype H34 constituted the largest portion of the population (21.5\%). One haplotype (H41) was shared with the Brewster subpopulation, four with Chelan (H31, H33, H36, and H56), and three with Wenatchee $(\mathrm{H} 31, \mathrm{H} 34$, and $\mathrm{H} 41)$. There were five haplotypes in the Puyallup subpopulation, and haplotypes H45 and H47 constituted $30 \%$ each of the total population. Only haplotype H45 was shared with the Wenatchee subpopulation. Haplotype H31 was found to occur in subpopulations from Chelan, Wenatchee, and Yakima, and constituted $28 \%$ of the total apple group population size,

TABLE 4. Pairwise comparison of genetic distance between Phacidiopycnis washingtonensis populations from different hosts using Slatkin's $R$ st value ${ }^{\mathrm{a}}$

\begin{tabular}{lccc}
\hline Hosts & Apple & Crabapple & Pacific Madrone \\
\hline Apple & 0.000 & $\ldots$ & $\ldots$ \\
Crabapple & 0.216 & 0.000 & $\ldots$ \\
Pacific Madrone & 0.134 & 0.475 & 0.000 \\
\hline
\end{tabular}

a Slatkin's $R$ st (Slatkin 1995) value of 0 indicates no separation, $0<R$ st $<0.05$ indicates negligible differentiation, $0.05<R$ st $<0.25$ indicates low differentiation, $0.25<R$ st $<0.5$ indicates moderate differentiation, $0.5<$ $R$ st $<1$ indicates high differentiation, and $R$ st $=1$ indicates complete differentiation (Hartl and Clark 2007).

TABLE 3. Subpopulation of Phacidiopycnis washingtonensis from each geographic area, with number of individuals of $P$. washingtonensis sampled under each subpopulation, observed number of haplotypes or genotypes $\left(g_{\text {obs }}\right)$, expected multilocus genotypes $\left(g_{\text {exp }}\right)$, clonal fraction $(\mathrm{CF})$, Nei's expected heterozygosity $\left(\mathrm{H}_{\mathrm{exp}}\right)$, indices of genotypic evenness (E.5), and indices of genotypic diversity ${ }^{\mathrm{a}}$

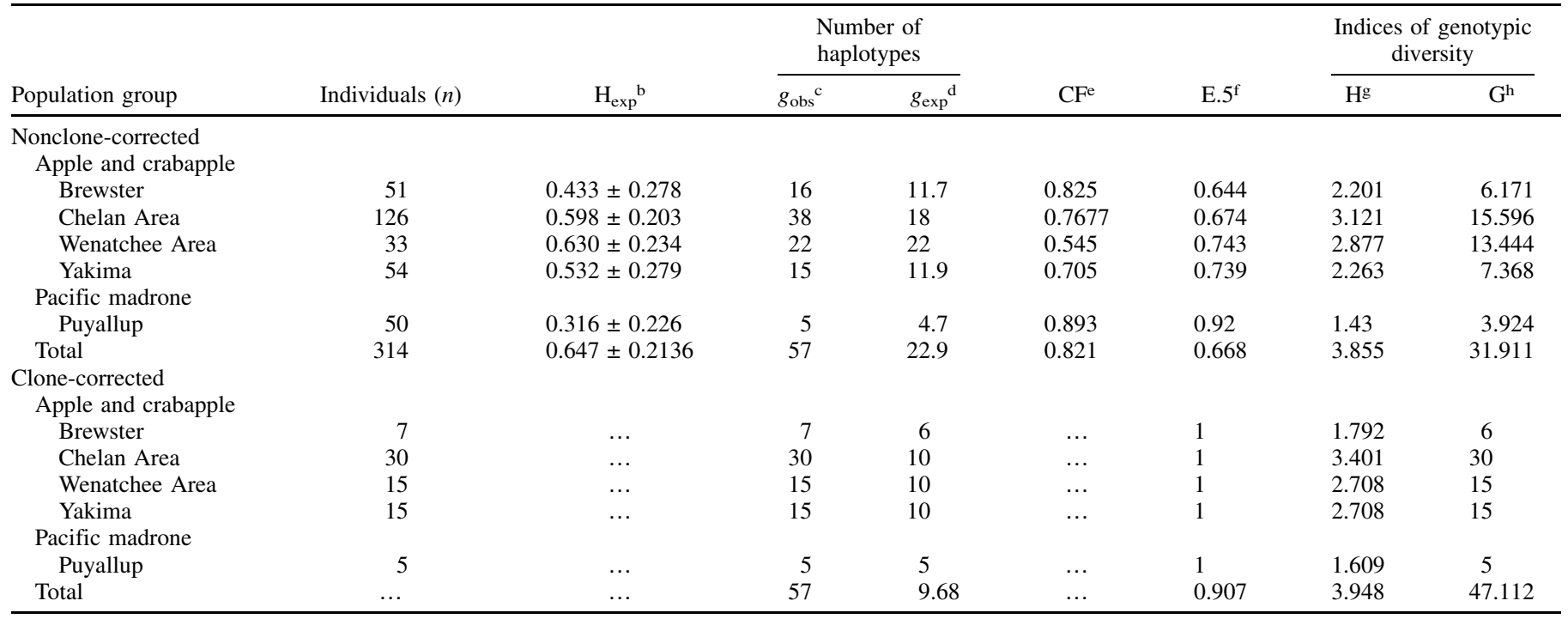

a All calculations were done in the poppr package of R Studio, version 3.0 (Kamvar et al. 2013).

b Nei's 1973 genotypic diversity (corrected for sample size), or expected heterozygosity. Calculated in Arlequin 3.5.

c Observed number of multilocus genotypes.

d Number of expected multilocus genotype at the smallest sample size $(n=5)$ based on rarefaction.

e $\mathrm{CF}=1-\{($ observed number of genotype)/(total number of isolates) $\}$ (Zhan et al. 2003).

f Genotypic evenness.

g Shannon-Wiener $(\mathrm{H})$ index ranges from 1.5 to 4 , where 1.5 means low genotypic diversity.

${ }^{\mathrm{h}}$ Stoddard-Taylor $(\mathrm{G})$ index ranges from 1 to sample size. A higher number indicates greater genotypic diversity. 
Nei's expected heterozygosity $\left(\mathrm{H}_{\mathrm{exp}}\right)$ ranged from 0.316 to 0.63 . $\mathrm{H}_{\text {exp }}$ was highest in the Wenatchee population (0.63) and lowest in the Puyallup population (0.32) (Table 3). The Shannon-Wiener genotypic diversity $(\mathrm{H})$ index ranged between 1.43 and 3.12 for nonclone-corrected data; it was highest within the apple population from Chelan and lowest within the Pacific madrone population from Puyallup. The overall Stoddard-Taylor diversity index was highest within the subpopulation from Chelan (15.59) and lowest in the Puyallup subpopulation (3.92) (Table 3). The index of genetic evenness indicated that the population of $P$. washingtonensis was genetically uniform because the index of genetic evenness was high $(>0.5)$ among all geographic locations, with the lowest being in the population from Brewster (0.64) and highest in the population from Puyallup (0.92) (Table 3).

According to AMOVA, there was $39.26 \%$ variation among subpopulations from different geographic areas and $69.51 \%$ difference within subpopulations $(P<0.05)$. AMOVA for clonecorrected data showed $4.50 \%(P=0.09)$ variation among subpopulations from different geographic locations and $98.50 \%$ difference within subpopulations $(P=0.014)$ (Table 5). Pairwise comparison of Slatkin's $R$ st showed that the population from Puyallup area was differentiated from most subpopulations of apple $(R \mathrm{st}=0.122$ to 0.214$)$ but highly different from the population from Brewster $(R \mathrm{st}=0.342)$ and was more similar to the Wenatchee subpopulation $(R \mathrm{st}=0.122)$. Populations from Wenatchee and Chelan showed a negligible difference $(R \mathrm{st}=0.074)$ (Table 6).

PCoA revealed three clusters, and percentages of variation were axis $1=57.62 \%$, axis $2=29.52 \%$, and axis $3=7.83 \%$. The Brewster population was in a separate coordinate $(\mathrm{x}=1.108, \mathrm{y}=0.148)$. Populations from Chelan $(\mathrm{x}=-0.099, \mathrm{y}=-0.062)$ and Yakima $(\mathrm{x}=$ $-0.237, \mathrm{y}=-0.033)$ were in axes 2 and the population from Wenatchee $(\mathrm{x}=-0.225, \mathrm{y}=-0.115)$ was clustered together with the Pacific madrone population from Puyallup $(\mathrm{x}=-0.460, \mathrm{y}=-0.372)$ (Fig. 2).

The mean number of alleles across all eight loci was 4.525 , and mean allelic size range was $89.1 \mathrm{bp}$. Numbers of private alleles ranged from 0.125 to 0.625 . The Brewster subpopulation had the lowest number of private alleles $(0.125)$ and the Chelan subpopulation had the highest number of private alleles $(0.625)$ (Table 7). Null hypothesis of recombination due to random mating within the subpopulation was rejected because the value of linkage disequilibrium indices $\left(\mathrm{I}_{\mathrm{A}}\right.$ and $\left.\mathrm{rBarD} \neq 0\right)$ was significantly greater than zero $(P<0.05)$. $\mathrm{I}_{\mathrm{A}}$ ranged between 0.724 and 2.577 and $\mathrm{rBarD}$ ranged between 0.105 and 0.441 (Table 7 ), suggesting that the fungus likely reproduced asexually in the populations we examined.

Haplotype H31 from the Chelan subpopulation occupied the center of the minimum spanning network. Of the five haplotypes, haplotype $\mathrm{H} 45$ from the Pacific madrone population from Puyallup originated from the center of the network, and there were five clusters of the Puyallup subpopulation. The H45 cluster was shared

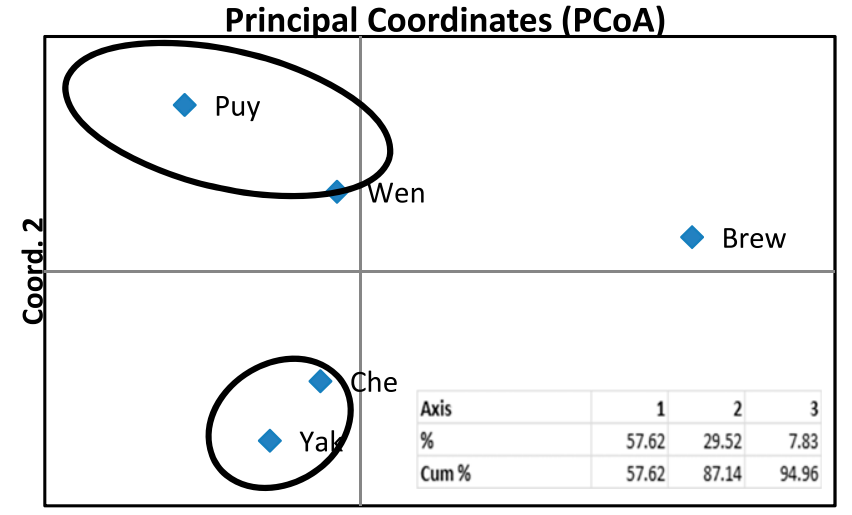

Coord. 1

Fig. 2. Principle coordinate analysis (PCoA) of different populations from different geographic areas in Washington State using the trimatrix of genetic distance between subpopulations expressed as Slatkin's Rst (Slatkin 1995) value generated in Genalex 6.5 (Peakall and Smouse 2006). Brew = Brewster, Che $=$ Chelan, Yak $=$ Yakima, Wen $=$ Wenatchee, and Puy $=$ Puyallup. Genetic distance is the estimate of the number of nucleotide base pair substitutions per gene locus that has accumulated during evolutionary time since the divergence of the taxa from their common ancestor (Drenth 1998).

TABLE 5. Analysis of molecular variance showing differences within population and among populations

\begin{tabular}{|c|c|c|c|c|c|c|}
\hline Source & $\mathrm{df}^{\mathrm{a}}$ & $\mathrm{SS}^{\mathrm{b}}$ & Estimated variance & Percent $^{\mathrm{c}}$ & $\Phi^{\mathrm{d}}$ & $P$ value \\
\hline \multicolumn{7}{|l|}{ Nonclone-corrected } \\
\hline Among apple group, Pacific madrone & 1 & $356,891.82$ & $-2,166.82$ & -8.77 & -0.087 & 0.6 \\
\hline Among geographic locations within hosts & 3 & $1,856,995.87$ & $9,695.54$ & 39.26 & 0.305 & 0.000 \\
\hline Total & 318 & 840.14 & 3.01 & $\ldots$ & $\ldots$ & $\ldots$ \\
\hline \multicolumn{7}{|l|}{ Clone-corrected } \\
\hline Among apple group, Pacific madrone & 1 & $45,512.08$ & -703.02 & -3.03 & -0.03 & 0.57 \\
\hline Among geographic locations within hosts & 3 & $116,809.15$ & $1,048.54$ & 4.526 & 0.0439 & 0.09 \\
\hline
\end{tabular}

${ }^{a}$ Degrees of freedom.

b Sum of squares.

${ }^{\mathrm{c}}$ Estimated percentage of genotypic variation.

d Fixation index which signifies inbreeding coefficient. Value $=0$ signifies random mating, value $=1$ signifies complete selfing, negative value signifies excess of heterozygotes due to disassortative mating or asexual reproduction, and values between 0 and 1 signify various levels of inbreeding (Goodwin 1997). Analyses were conducted using Arlequin 3.5 (Excoffier et al. 2005).

TABLE 6. Pairwise comparison of genetic distance expressed as Slatkin's Rst values for Phacidiopycnis washingtonensis subpopulations from different geographic areas in Washington State ${ }^{\mathrm{a}}$

\begin{tabular}{|c|c|c|c|c|c|}
\hline Geographic location & Brewster & Chelan & Wenatchee & Yakima & Puyallup \\
\hline Brewster & $0.000(0.000)$ & & & & .. \\
\hline Chelan & $0.187(0.096)$ & $0.000(0.000)$ & - & $\ldots$ & $\ldots$ \\
\hline Wenatchee & $0.239(0.232)$ & $0.075(0.014)$ & $0.000(0.000)$ & $\ldots$ & $\ldots$ \\
\hline Puyallup & $0.342(0.266)$ & $0.167(0.285)$ & $0.122(0.000)$ & $0.214(0.093)$ & $0.000(0.000)$ \\
\hline
\end{tabular}

a Slatkin's $R$ st (Slatkin 1995) value of 0 indicates no separation, $0<R$ st $<0.05$ indicates negligible differentiation, $0.05<R$ st $<0.25$ indicates low differentiation, $0.25<R$ st $<0.5$ indicates moderate differentiation, $0.5<R$ st $<1$ indicates high differentiation, and $R$ st $=1$ indicates complete differentiation (Hartl and Clark 2007). Values in parenthesis indicate $R$ st values for clone-corrected data. 
between the Puyallup population and the subpopulation of the apple group from Wenatchee area. Haplotype H11 from Brewster constituted the largest size in the subpopulation (Fig. 3).

Pathogenicity. Leaf blight symptoms were apparent within 15 to $25 \mathrm{dpi}$ under greenhouse conditions and expanded from the leaf stem toward the margin of the leaves. All isolates of $P$. washingtonensis belonging to haplotypes $\mathrm{H} 31, \mathrm{H} 45, \mathrm{H} 42$, and $\mathrm{H} 47$ caused leaf blight on Pacific madrone leaves under greenhouse conditions. However, a cold injury predisposition to the inoculation sites prior to inoculation facilitated the development of leaf blight. For all isolates, blight development was observed on $100 \%$ of leaves predisposed to cold treatment prior to inoculation. In the absence of cold predisposition, only isolate 8309 (H47) from Pacific madrone and isolate 3045 (H31) from apple caused leaf blight on Pacific madrone. Isolates 8309 and 3045 resulted in blight in 80 and $70 \%$ of inoculated leaves, respectively. Because the symptoms appeared at different days postinoculation and also showed differences in the spread of blight over time, AUDPC was calculated. For noncoldpredisposed, inoculated leaves, isolates 3045 and 8309 caused significant blight on the leaves. For cold-predisposed, inoculated leaves, there were significant differences in AUDPC among the isolates. Isolates 8347, 8309, 8345, 8308, and 8307 (originally isolated from Pacific madrone) induced a higher disease severity index compared with the isolates 3101,4183 , and 4185 (originally isolated from apple), and these differences were significant (Fig. 4A). P. washingtonensis was recovered on PDA from the margin of healthy and diseased tissues as well as from the center of blighted leaves.

All isolates of $P$. washingtonensis tested in this study were able to cause decay symptoms on inoculated apple fruit, and all apple fruit inoculated with any of the tested isolates, regardless of their haplotypes, developed speck rot symptoms. Decay symptoms began to appear $10 \mathrm{dpi}$. The diameters of speck rot lesions on apple fruit increased over time. However, there were visible differences in lesion expansion on apple inoculated with different isolates. Significant differences in disease severity index were observed among isolates $(P<0.001)$, with isolates 8307 and 8308 having the highest severity index expressed as AUDPC, and isolates 4183 and 8347 belonging to haplotype $\mathrm{H} 45$ had the lowest disease severity index (Fig. 4B). However, the differences in severity index were regardless of the host origins of the isolates. P. washingtonensis was reisolated from symptomatic tissues of all decayed apple fruit.

\section{DISCUSSION}

P. washingtonensis has been reported from multiple host plants that are both taxonomically different and geographically isolated. Understanding the genetic structure of $P$. washingtonensis populations from different hosts and geographic locations may assist in the development of control measures. In the current study, we examined genotypic diversity and evaluated genotypic variations among and within the populations of $P$. washingtonensis alongside the conduct of cross pathogenicity tests. These studies indicated that the genetic diversity observed was mainly within the subpopulation of $P$. washingtonensis from the apple group in different geographic locations and within the Pacific madrone population.

$P$. piri, which is the cause of Phacidiopycnis rot, a postharvest disease of apple and pear fruit, is a species closely related to P. washingtonensis (Xiao et al. 2005). Previously, sequencecharacterized amplified region (SCAR) markers were developed to examine the population genetic structure of $P$. piri from different geographic locations in the U.S. Pacific Northwest (Liu et al. 2009). Use of SCAR markers was not suitable for examination of $P$. washingtonensis populations because it yielded insufficient polymorphism to discriminate differences among isolates (data not shown). RAPD and microsatellite-primed PCR markers were also not useful because of insufficient polymorphic regions to understand the population genetic structure of the pathogen (data not shown). Thus, in the current study, we developed eight microsatellite markers which exhibited polymorphism across all loci and have been demonstrated to be useful markers for understanding the

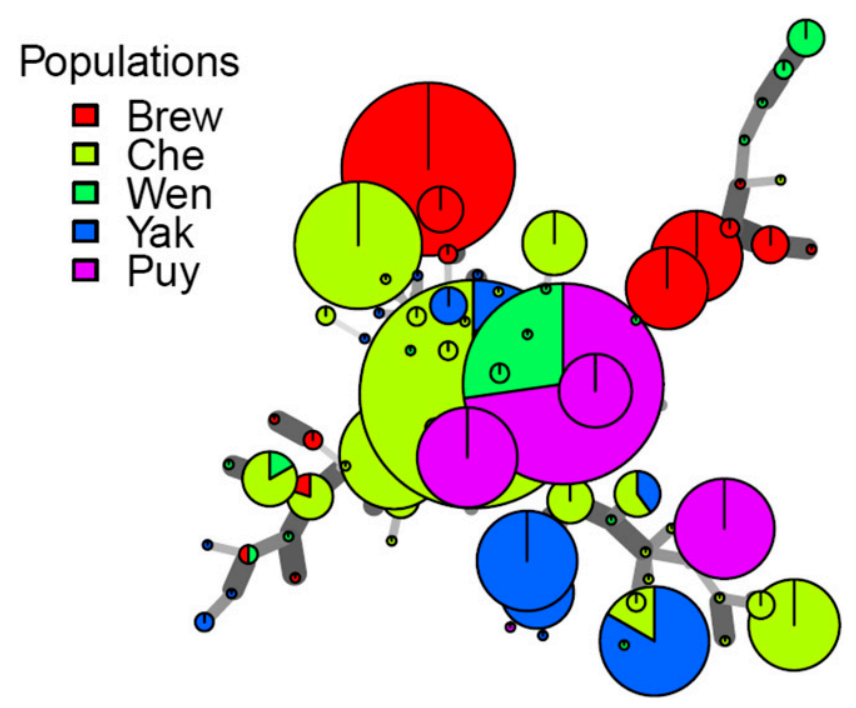

Fig. 3. Minimum spanning networks joining genetic distance expressed in Bruvo's distance between multilocus genotypes (MLG) in each subpopulation of Phacidiopycnis washingtonensis belonging to different geographic locations. Red indicates population from Brewster (Brew), light green from Chelan (Che), dark green from Wenatchee (Wen), blue from Yakima (Yak), and purple from Puyallup area (Puy). Distances between haplotypes are based on genetic distances calculated using a stepwise mutation model from Bruvo's genetic distance (Bruvo et al. 2004) in the poppr package in R Studio (Kamvar et al. 2013). Gray lines represent each mutation step. Each pie graph represents one haplotype. Size of each pie is scaled according to haplotype frequencies, and the distribution of the haplotypes in different subpopulations is represented by the colors.

TABLE 7. Observed number of alleles (Na), effective number of alleles $(\mathrm{Ne})$, number of private alleles $(\mathrm{NPa})$, index of association $\left(\mathrm{I}_{\mathrm{A}}\right)$, and linkage disequilibrium (rBarD) in populations of Phacidiopycnis washingtonensis from different geographic locations in Washington State

\begin{tabular}{|c|c|c|c|c|c|c|c|}
\hline \multirow[b]{2}{*}{ Location } & \multirow[b]{2}{*}{$N^{\mathrm{b}}$} & \multirow[b]{2}{*}{$\mathrm{Na}$} & \multirow[b]{2}{*}{$\mathrm{Ne}$} & \multirow[b]{2}{*}{$\mathrm{NPa}$} & \multicolumn{3}{|c|}{ Indices of linkage disequilibrium $^{\mathrm{a}}$} \\
\hline & & & & & $\mathrm{I}_{\mathrm{A}}^{\mathrm{c}}$ & $\mathrm{rBarD}^{\mathrm{d}}$ & $P$ value \\
\hline Brewster & 51 & $3.375 \pm 0.565$ & $2.105 \pm 0.313$ & 0.125 & $2.577(1.025)$ & $0.441(0.213)$ & $<0.005(0.002)$ \\
\hline Chelan & 126 & $6.125 \pm 1.093$ & $3.076 \pm 0.531$ & 0.625 & $1.096(0.454)$ & $0.158(0.067)$ & $<0.005(0.03)$ \\
\hline Wenatchee & 33 & $5.375 \pm 0.822$ & $3.379 \pm 0.595$ & 0.500 & $1.373(0.263)$ & $0.199(0.039)$ & $<0.005(0.002)$ \\
\hline Yakima & 54 & $5.375 \pm 0.925$ & $2.966 \pm 0.668$ & 0.375 & $1.957(0.313)$ & $0.298(0.047)$ & $<0.005(<0.005)$ \\
\hline Puyallup & 50 & $2.375 \pm 0.324$ & $1.596 \pm 0.185$ & 0.375 & $1.406(0.290)$ & $0.281(0.058)$ & $<0.005(0.01)$ \\
\hline Total & 314 & $4.525 \pm 0.404$ & $2.624 \pm 0.234$ & $\ldots$ & $0.724(0.377)$ & $0.105(0.055)$ & $<0.005(0.01)$ \\
\hline
\end{tabular}

a Values in parenthesis indicate clone-corrected data.

b Number of individuals.

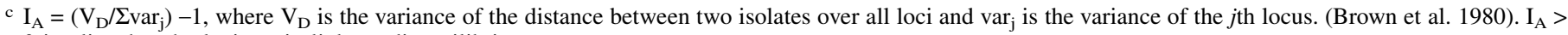
0 implies that the loci are in linkage disequilibrium.

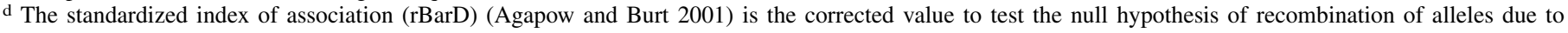
random mating, and values of $\mathrm{rBarD}>0$ signify no random mating (i.e., population does not have a sexual mode of reproduction). 
population genetic structure of $P$. washingtonensis. These markers were used because of their higher allelic frequency per locus and complex microsatellite repeat motifs. Microsatellite markers with more complex repeat patterns are preferred because the mutation rates occurring at these loci, which result in polymorphic alleles at each locus, are more reliable compared with simple or single nucleotide repeats (Brown 1996).

The 58 haplotypes identified in this study were distributed among the different populations of $P$. washingtonensis, and 12 of them occurred multiple times across pathogen populations from different geographic areas. However, only one haplotype was shared between the apple group population and the Pacific madrone population. Twelve common haplotypes were distributed within apple group subpopulations from different geographic areas. The presence of common genotypes among pathogen populations indicates the occurrence of gene flow among the populations (McDonald and Linde 2002; Ozkilinc et al. 2010). Thus, there was a relatively lower gene flow rate between the apple group population and Pacific madrone population, and a higher rate of gene flow appeared to be occurring among the subpopulations of the apple group population from different geographic areas. In the current study, the apple subpopulations from Chelan, Wenatchee, Yakima, and Brewster possessed higher genotypic diversity compared with the Pacific madrone population from Puyallup. High gene diversity is often attributed to high gene flow, as was observed within the subpopulations of the apple group population, because higher gene flow increases effective population size which, in turn, increases the genetic diversity (McDonald and Linde 2002). Indices of linkage disequilibrium $\left(\mathrm{I}_{\mathrm{A}}\right.$ and $\mathrm{rBarD} \neq 0$ ) and $\mathrm{CF}$ value suggest that populations of $P$. washingtonensis examined in this study likely exhibited an asexual mode of reproduction. This also is supported by the fact that no sexual state of $P$. washingtonensis occurring in nature has been observed (Xiao et al. 2005) (C. L. Xiao, personal observation). Pathogens with an asexual mode of reproduction pose the risk of evolving into virulent strains because asexual propagules are like "linked package of co-adapted alleles" which are selected under natural selection (McDonald and Linde 2002). The $P$. washingtonensis isolates from persimmon from Italy shared one unique haplotype. However, the sample size of $P$. washingtonensis from persimmon was limited to four isolates; hence, this likely affected the observed number of genotypes among this population. A larger sample collection of both apple and persimmon isolates from Europe could give a better understanding of the relationship of the populations of $P$. washingtonensis from Europe and North America. In the present study, the persimmon population was treated as an outlier and no further analysis was carried out with this population.

Despite the genotypic flow among the subpopulations from different geographic regions within the apple group population, there existed the presence of private alleles. Frequency of private alleles was higher in the population from apple compared with that from Pacific madrone. The presence of private alleles in a population reflects population differentiation and could have contributed to the observed divergence between the populations from different geographic regions (Ozkilinc et al. 2010).

In our study, AMOVA did not show genetic differentiation between the apple group population and Pacific madrone population. However, AMOVA indicated that there was genetic differentiation within isolates of subpopulations of the apple group from different geographic areas and also within isolates of the Pacific madrone population from Puyallup. These results are in agreement with high genotypic diversity indices observed within the subpopulations of the apple group population, as mentioned above. A similar observation was made in population genetics study of Didymella rabei from chickpea production areas in Israel and Turkey (Ozkilinc et al. 2010). The lack of genetic diversity between the populations of $P$. washingtonensis from two different hosts indicates that the pathogen is well established on both apple and Pacific madrone, which was further supported by the pathogenicity tests conducted in the greenhouse and laboratory because the isolates from Pacific madrone leaves were able to infect apple fruit or vice versa.

The center of origin of any pathogen or organism is likely to possess a population with higher genetic variability compared with recently established populations (Stukenbrock et al. 2006). In the current study, $P$. washingtonensis populations from apple have higher genotypic diversity than the population from Pacific madrone, suggesting that the apple populations could have become established earlier in the apple production areas in eastern Washington. Apple production began in the western United States in the early nineteenth century. Apple is produced on over 127,832 ha in Washington State (USDA-NASS 2016). Commercial apple production in Washington State is located primarily in central Washington under a semiarid climate, on the east side of the Cascade mountain range. Pacific madrone, on the other hand, grows along the Pacific coast from British Columbia, Canada to California in the United States These plants are native to the coastal areas along the west side of Cascade Range and Klamath Mountains in California. Pacific madrone trees require a moderate temperature and abundant rainfall for their growth, unlike apple trees, which survive in a wide

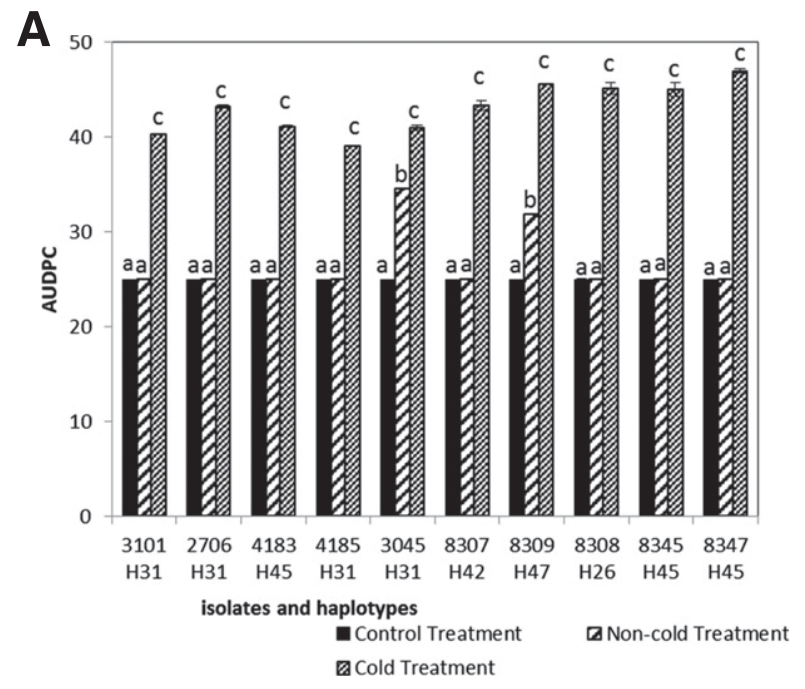

B

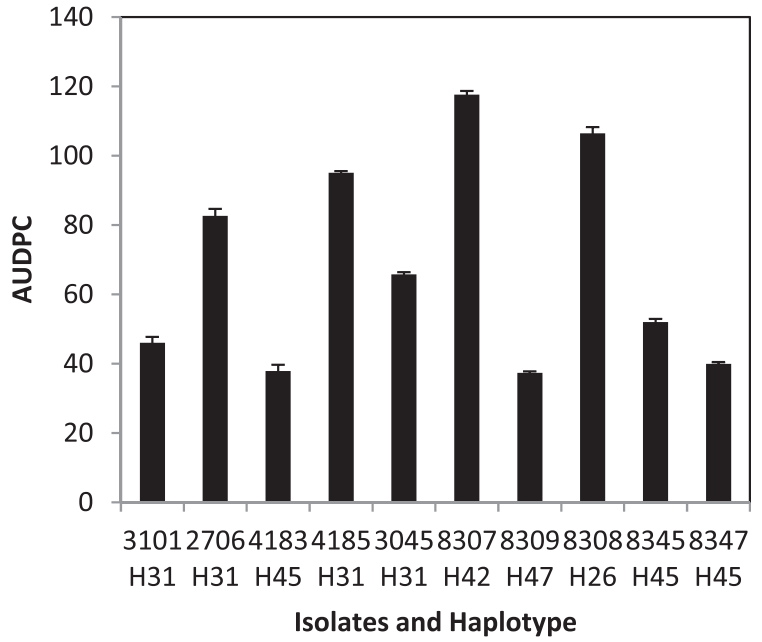

Fig. 4. Area under disease progress curve (AUDPC) values for A, blight on Pacific madrone leaves inoculated in the greenhouse up to 35 days postinoculation and $\mathbf{B}$, speck rot expressed as lesion diameter (in millimeters) on Red Delicious apple fruit following inoculation with different haplotypes of Phacidiopycnis washingtonensis up to 22 days postinoculation at $0^{\circ} \mathrm{C}$. Isolates 2706 (H31), 3101 (H31), 3045 (H31), 4185 (H31), and 4183 (H45) were from apple and 8307 (H42), 8308 (H47), 8309 (H47), 8345 (H45), and 8347 (H45) were from Pacific madrone. 
range of climatic conditions from extreme subzero conditions in winter to hot summers. Apple is grown in a managed agroecosystem, unlike Pacific madrone, and newer varieties of apple have been introduced over the centuries through breeding. Introduction of newer genetic traits in apple could have resulted in the coevolution of $P$. washingtonensis in apple production areas, which may explain the existence of higher levels of genotypic diversity within this apple population. In the current study, a large number of $P$. washingtonensis isolates from apple were collected from different locations across north-central Washington State. A larger sampling size often gives rise to higher genotypic diversity because more alleles could emerge through mutation and fewer alleles will be lost due to random genetic drift (Kimura 1983). The sample size of Pacific madrone isolates was smaller and also concentrated from the Puyallup area alone. Due to loss of alleles over time resulting from genetic drift and natural selection of favorable alleles, it is often noticed that plant pathogen populations with a small sample size have lesser genotypic diversity (Mc Donald 2004). Low genotypic diversity observed in the Puyallup population could be attributed to its small sample size.

In our study, we were not able to obtain more isolates of $P$. washingtonensis from Europe. Thus, we did not intend to extrapolate the data from this limited number of isolates as to whether $P$. washingtonensis originates from Europe, the United States, or other regions. Although apple is native to Central Asia, $P$. washingtonensis has not been reported to be present there. However, both minimum spanning network and PCoA suggest that, within Washington State, $P$. washingtonensis likely originated in the apple production area. Haplotype H45 commonly occurred within the Wenatchee population and Puyallup population at a high frequency. Although the sample size was comparable, the Wenatchee population possessed a higher genotypic diversity than the Puyallup population for both clone- and nonclone-corrected data sets. Usually the older and larger populations tend to have higher genotypic diversity than newer, recently established populations or smaller-size populations (Stukenbrock et al. 2006). In our study, we could rule out the possibility of sample size contributing to the difference in genotypic diversity between these two subpopulations. It is possible that movement of plant materials could have contributed to the introduction of the pathogen to the west side of the Cascade Mountains where Pacific madrone is grown. However, collection of $P$. washingtonensis from a larger area where Pacific madrone grows naturally could provide a better understanding of the origin of this pathogen within the U.S. Pacific Northwest and whether it migrated from the apple production area to native habitat of the Pacific madrone or vice versa.

Pathogenicity tests conducted in the laboratory and greenhouse showed that isolates of $P$. washingtonensis from apple were able to infect Pacific madrone and vice versa. As mentioned earlier, populations of $P$. washingtonensis from different geographic locations among the subpopulations of apple exhibited high rates of genotypic flow. The ability of cross infection between apple and Pacific madrone isolates suggests that apple, crabapple, and Pacific madrone could act as sources of inoculum for the pathogen.

\section{ACKNOWLEDGMENTS}

We thank M. Elliott for providing seedlings of Pacific madrone for the pathogenicity tests; A. Garibaldi for providing isolates of $P$. washingtonensis from Italy; and R. Boal, M. Walter and C. G. Aguilar for assistance with greenhouse experiments. Mention of trade names or commercial products in this article is solely for the purpose of providing specific information and does not imply recommendations or endorsement by the U.S. Department of Agriculture. USDA is an equal opportunity provider and employer.

\section{LITERATURE CITED}

Agapow, P. M., and Burt, A. 2001. Indices of multilocus linkage disequilibrium. Mol.17 Ecol. Notes 1:101-102.
Baumgartner, K., Travadon, R., Bruhn, J., and Bergemann, S. E. 2010. Contrasting patterns of genetic diversity and population structure of Armillaria mellea sensu stricto in the eastern and western United States. Phytopathology 100:708-718.

Brown, J. K. M. 1996. The choice of molecular marker methods for population genetic studies of plant pathogens. New Phytol. 133:183-195.

Brown, A. H. D., Feldman, M. W., and Nevo, E. 1980. Multilocus structure of natural populations of Hordeum spontaneum. Genetics 96:523-536.

Bruvo, R., Michiels, N. K., D'Souza, T. G., and Schulenburg, H. 2004. A simple method for the calculation of microsatellite genotype distances irrespective of ploidy level. Mol. Ecol. 13:2101-2106.

Drenth, A. 1998. Pages 38-39 in: A practical guide to population genetics. University of Queensland, Brisbane, Australia.

Dung, J. K., Peever, T. L., and Johnson, D. A. 2013. Verticillium dahliae populations from mint and potato are genetically divergent with predominant haplotypes. Phytopathology 103:445-459.

Elliott, M., Chastagner, G. A., Coats, K. P., Sikdar, P., and Xiao, C. L. 2014. First Report of a New Leaf Blight Caused by Phacidiopycnis washingtonensis on Pacific Madrone in Western Washington and Oregon. Plant Dis. 98:1741.

Excoffier, L., Laval, G., and Schneider, S. 2005. Arlequin (version 3.0): An integrated software package for population genetics data analysis. Evol. Bioinf. 1:47-50.

Ferrucho, R. L., Ceresini, P. C., Ramirez-Escobar, U. M., McDonald, B. A., Cubeta, M. A., and Garcia-Dominguez, C. 2013. The population genetic structure of Rhizoctonia solani AG-3PT from potato in the Columbian Andes. Phytopathology 103:862-869.

Garibaldi, A., Bertetti, D., Amatulli, M. T., and Gullino, M. L. 2010. First report of postharvest fruit rot in persimmon caused by Phacidiopycnis washingtonensis in Italy. Plant Dis. 94:788.

Glenn, T. C., and Schable, N. A. 2005. Isolating microsatellite DNA loci. Methods Enzymol. 395:202-222.

Goodwin, S. B. 1997. The population genetics of Phytophthora. Phytopathology 87:462-473.

Green, M. R., and Sambrook, J. 2012. Molecular Cloning: A Laboratory Manual. Cold Spring Harbor Laboratory, Cold Spring Harbor, New York.

Grünwald, N. J., Goodwin, S. B., Milgroom, M. G., and Fry, W. E. 2003. Analysis of genotypic diversity data for populations of microorganisms. Phytopathology 93:738-746.

Hamilton, M. B., Pincus, E. L., DiFiore, A., and Fleischer, R. C. 1999. Universal linker and ligation procedures for construction of genomic DNA libraries enriched for microsatellites. Biotechniques 27:500-507.

Hartl, D. L., and Clark, A. G. 2007. Principles of Population Genetics. Sinauer Associates Inc. Publishers, Sunderland, MA.

Kim, Y. K., and Xiao, C. L. 2006. A postharvest fruit rot in apple caused by Phacidiopycnis washingtonensis. Plant Dis. 90:1376-1381.

Kimura, M. 1983. The Neutral Theory of Molecular Evolution. Cambridge University Press, New York.

Koressaar, T., and Remm, M. 2007. Enhancements and modifications of primer design program Primer3. Bioinformatics 23:1289-1291.

Liu, Q., Peever, T. L., and Xiao, C. L. 2009. Population structure of Potebniamyces pyri in the U.S. Pacific Northwest and evidence of outcrossing inferred with sequence-characterized amplified region markers. Phytopathology 99:532-539.

Maciel, J. L. N., Ceresini, P. C., Castrogaudin, V. L., Zala, M., Kema, G. H. J., and McDonald, B. A. 2014. Population structure and pathotype diversity of the wheat blast pathogen Magnaporthe oryzae 25 years after its emergence in Brazil. Phytopathology 104:95-107.

Mann, H. B., and Whitney, D. R. 1947. On a test of whether one of two random variables is stochastically larger than the other. Ann. Math. Stat. 18:50-60.

McDonald, B. A. 2004. Population Genetics of Plant Pathogens. Online publication. Plant Health Instruct.

McDonald, B. A., and Linde, C. 2002. Pathogen population genetics, evolutionary potential and durable resistance. Annu. Rev. Phytopathol. 40: 349-379.

Meirmans, P. G., and Van Tienderen, P. H. 2004. GENOTYPE and GENODIVE: Two programs for the analysis of genetic diversity of asexual organisms. Mol. Ecol. Notes 4:792-794.

Milgroom, M. G., and Peever, T. L. 2003. Population biology of plant pathogens. Plant Dis. 87:608-617.

Nei, M. 1973. Analysis of gene diversity in subdivided populations. Proc. Natl. Acad. Sci. USA 70:3321-3323.

Ohta, T., and Kimura, M. 1973. A model of mutation appropriate to estimate the number of electrophoretically detectable alleles in a finite population. Genet. Res. 22:201-204.

Ozkilinc, H., Frenkel, O., Abbo, S., Eshed, R., Sherman, A., Shtienberg, D., Ophir, R., and Can, C. 2010. A comparative study of Turkish and Israeli populations of Didymella rabiei, the ascochyta blight pathogen of chickpea. Plant Pathol. 59:492-503. 
Ozkilinc, H., Akamatsu, H., Abang, M., Thomas, K., Chilvers, M. I., and Peever, T. L. 2011. Development, characterization and linkage analysis of microsatellite loci for the Ascochyta blight pathogen of faba bean, Didymella fabae. J. Microbiol. Methods 87:128-130.

Peakall, R. O. D., and Smouse, P. E. 2006. GENALEX 6: Genetic analysis in Excel. Population genetic software for teaching and research. Mol. Ecol. Notes 6:288-295.

Peever, T. L., Salimath, S. S., Su, G., Kaiser, J., and Muehlnaur, F. J. 2004. Historical and contemporary multilocus population structure of Ascochyta rabiei (teleomorph: Didymella rabiei) in the Pacific Northwest of the United States. Mol. Ecol. 13:291-309.

Rice, W. R. 1989. Analyzing tables of statistical test. Evolution. 43:223-225.

Saiki, R. K., Scharf, S., Faloona, F., Mullis, K. B., Erlich, H. A., and Arnheim, N. 1985. Enzymatic amplification of beta-globin genomic sequences and restriction site analysis for diagnosis of sickle cell anemia. Science 230: 1350-1354.

Schlotterer, C. 2000. Evolutionary dynamics of microsatellite DNA. Chromosoma 109:365-371.

Selkoe, A. K., and Toonen, R. J. 2006. Microsatellites for ecologists: A practical guide to using and evaluating microsatellite markers. Ecol. Lett. 9: 615-629.

Slatkin, M. 1995. A measure of population subdivision based on microsatellite allele frequencies. Genetics 139:457-462.

Stoddart, J. A., and Taylor, J. F. 1988. Genotypic diversity: Estimation and prediction in samples. Genetics 118:705-711.
Stukenbrock, E. H., Banke, S., and McDonald, B. A. 2006. Global migration pattern in the fungal wheat pathogen Phaeosphaeria nodorum. Mol. Ecol. 15:2895-2904.

USDA-NASS. 2015. Noncitrus Fruits and Nuts, 2014 preliminary summary. Online publication. United States Department of Agriculture-National Agricultural Statistics Service. https://usda.mannlib.cornell.edu/usda/nass/ NoncFruiNu/2010s/2016/NoncFruiNu-07-06-2016.pdf

Vos, P., Hogers, R., Bleeker, M., Reijans, M., Lee, T. V. D., Hornes, M., Frijters, A., Pot, J., Peleman, J., Kuiper, M., and Zabeau, M. 1995. AFLP: A new technique for DNA fingerprinting. Nucleic Acids Res. 23:4407-4414.

Weber, W. S. R. 2011. Phacidiopycnis washingtonensis, cause of a new storage rot of apples in Northern Europe. J. Phytopathol. 159:682-686.

Williams, J. G. K., Kubelik, A. R., Livak, K. J., Rafalski, J. A., and Tingey, S. V. 1990. DNA polymorphisms amplified by arbitrary primers are useful as genetic markers. Nucleic Acids Res. 18:6531-6535.

Xiao, C. L., Kim, Y. K., and Boal, R. J. 2009. A new canker disease of crabapple trees caused by Phacidiopycnis washingtonensis in Washington State. Online publication. Plant Health Prog. 10.

Xiao, C. L., Rogers, J. D., Kim, Y. K., and Liu, Q. 2005. Phacidiopycnis washingtonensis - a new species associated with pome fruits from Washington State. Mycologia 97:464-473.

Zhan, J., Pettway, R. E., and McDonald, B. A. 2003. The global genetic structure of the wheat pathogen Mycosphaerella graminicola is characterized by high nuclear diversity, regular recombination, and gene flow. Fungal Genet. Biol. 38:286-297. 